\title{
Social Integration As A Direction For Humanization Of Economic Relations And Improvement Of Social Welfare
}

https://doi.org/10.21272/sec.3(4).52-62.2019

Olena Voronkova, ORCID: $\underline{\text { htps://orcid.org/0000-0002-7956-7768 }}$

Doctor of Economics, Professor, Financial Markets Department, University of the State Fiscal Service of Ukraine, USFSU, Ukraine

Oksana Hordei, ORCID: https://orcid.org/0000-0001-6938-0548

Doctor of Economics, Professor, Finance Department, University of the State Fiscal Service of Ukraine, USFSU, Ukraine

Andala Rama Putra Barusman ORCID: https://orcid.org/0000-0002-2183-7593

$\mathrm{PhD}$ in Economics, Dean of Economics Faculty, University of Bandar Lampung, Indonesia

Erlane K. Ghani, ORCID: https://orcid.org/0000-0001-5539-0569

$\mathrm{PhD}$ in Economics, Associate Professor in Accounting, University Teknologi MARA, Malaysia

\begin{abstract}
The results of the implementation of EU policy in the field of social protection and social security are multidimensional particularly in the aspects of income and living standards, access to qualitative health care, education and work opportunities. Social integration is an instrument for achievement of these results especially promoting employment and poverty alleviation as well as monitoring the progress made in social protection. The aim of the paper is to study the process of social integration in the field of the promotion for social unity, gender equality and equal opportunities for all segments of the population (children, youth, retirees, disabled people) through flexible and effective social protection systems and social security policies. Systematic and evolutionary approaches, methods of observation, comparison, generalization and extrapolation were used in the study. The tools of social integration of people with disabilities to ensure their access to lifelong learning and employment are considered as they are the most vulnerable in society. The necessity of social integration and development of civic responsibility of youth is studied in order to realize the unity of goals, objectives and national priorities at different levels of economic and social development of society. This is especially important in the context of financial disproportion and significant social and economic differentiation of both the population and regions. A comprehensive approach to the development of major state programs and public welfare programs is inherent in a socially oriented and human-centered market economy. In the process of financing public welfare, the main goals of public policy implementation should be a support of welfare of both individuals and households; overcoming poverty; increase of economic efficiency of functioning of all processes of social integration. The modern economic theories of public welfare and human capital were also used. It is proved that in order to implement social integration successfully it is necessary: to improve the financial mechanism and normative base aimed at creating an effective system of targeted social payments; to provide implementation of a set of measures for the development and improvement of social services for the poor; to develop and implement measures for the prevention of disability and social integration of the disabled; to involve non-governmental organizations, associations and individuals in solution of social problems.
\end{abstract}

Keywords: social integration, social protection, sustainable development, public welfare, poverty, economic development, strategic transformations.

JEL Classification: B15, B25, D31, 63, J14.

Cite as: Voronkova, O., Hordei, O., Barusman, A.R.P., Ghani, E.K. (2019). Social Integration As A Direction For Humanization Of Economic Relations And Improvement Of Social Welfare. SocioEconomic Challenges, 3(4), 52-62. https://doi.org/10.21272/sec.3(4).52-62.2019.

(C) The Authors, 2019. This article is published with open access at Sumy State University. 


\section{Introduction}

The sustainable development of a market economy, the preservation and rational use of wealth in the interests of both present and future generations envisage the integration of the governmental efforts, social integration, integration of the national economies in the world economy through the development of various forms of economic cooperation. Decree of the President of Ukraine 'On the Strategy of Sustainable Development Ukraine 2020' envisages the achievement of economic and social development in the context of the international commitments undertaken by Ukraine by signing international agreements with UNDP, the EU and the IMF. This Strategy includes a comprehensive set of strategic transformations, the implementation of which will have a positive impact on the processes of social integration and improvement of social welfare.

The UN Global Compact is the largest corporate initiative on sustainable development in the world. Thanks to him, entrepreneurs work together to improve their work and to adhere to universal human rights principles in particular labor rights, environmental protection, social integration and the fight against corruption, and take measures to implement Sustainable Development Goals (SDGs).

In the process of public welfare improvement, the main goals of both public and private institutions should be: support the welfare of both individuals and households; poverty alleviation; strengthening of social integration; increase of economic efficiency.

National governments are primarily responsible for employment and implementation of social policy. EU funding supports and complements their efforts. To counteract the effects of demographic aging, the EU's social integration policy is designed to make it easier for young people to find work, to modernize social protection systems, to ensure the free movement of workers between countries, to reduce poverty and to protect people with disabilities.

The EU also coordinates and controls national policies, encourages its members to apply the best practices in social integration, poverty alleviation and pensions increase; supports learning, skills development and entrepreneurship; develops laws on employee rights, eliminates discrimination at work and coordinates social security mechanisms and monitors their implementation.

The organized social system is endowed with the ability to choose independently the ways of action in accordance with common goals. The participants in the social system are purposeful individuals and institutions that are able to make choices not only in accordance with their personal needs but also the public needs. If this opportunity is not realized we are dealing with an unorganized social group in which individual elements, although they are purposeful, cannot make a goal-oriented choice by the whole group. In order to eliminate such imbalances, social integration is foreseen.

Social Integration: Approaches and Issues (March 1994) is a complex idea, which means different things to different people. To some, it is a positive goal, implying equal opportunities and rights for all human beings. In this case, becoming more integrated implies improving living chances.

\section{Literature review}

Social integration is impossible without use of the needs theory. We distinguish two directions of the development of the needs theory: social direction, which was investigated by Mayo E. (1946), Owen R. (1817), McGregor D. (1960) and psychological direction, which was investigated by Maslow A. (1954), Alderfer C. (May 1969), Herzberg F. (1966).

The theory of basic needs, for example Abraham H. Maslow (1954) based on the well-known theory of the needs of American scholar Abraham H. Maslow, is very important. According to it, there were distinguished five conditional groups of needs that were in a pyramidal dependence.

One of theoretical and methodological concepts for definition of social welfare was the Western neoclassical school. Her representative was the English scholar Arthur Cecil Pigou (1920). Basing on his considerations, the welfare was characterized by the size of national income per capita. This integral indicator, in its turn, depends on many factors: the volume of resources and capital, the characteristics of the population (income distribution, the number of non-working people in households, traditions, customs, etc.), government activity and conditions of foreign trade. In his opinion the improvement of welfare could be achieved through a more even distribution of incomes through governmental intervention in particular rational taxation. 
Representatives of the methodology of technological determinism (Bell D. (1973), R. F. Kahn (Jun., 1931), J. Viner (1925)), who defined the concept of utility in the welfare economy according to with which 'individual welfare' can be determined basing not only on the subjective degree of the needs satisfaction that the individual receives from the consumption of goods or a set of benefits, but will be also formed in direct proportion to the increase in funding for science and technique. They are seen as a carrier of new social and economic and human values. They believe that the growth of technical capacities for both human and for society is a phenomenon that will promote employment. The questions of the technique impact on human, the meaning of human life and human dignity are considered in the context of the adapting possibility of an individual to his or her welfare in a competitive society that functions according to market principles of economy.

Well-known scientists in the field of 'system approach' Russell Lincoln Ackoff, Frederick Edmund Emery (1972) distinguished not only system features such as functionality, structuring, purposefulness, but also proved the need to use a systematic approach for study any phenomenon or process as a whole.

Numerous works of economists and financiers cover the issues of maximum satisfaction of the needs and interests of individuals, but are limited to mathematical analysis without meaningful financial interpretation and without comparison of the welfare level e and social integration.

\section{Methods}

The methodological and theoretical basis of the article are the fundamental classical and contemporary works of Western and domestic scientists. An evolutionary approach has been applied to study the stages of development of social integration in European countries.

The system approach is used to describe the place of social integration in the system of social protection. The theory of knowledge, in which the system is regarded as a set of interrelated elements, united by a single purpose and functional integrity, while the system acquires new properties, and not reduces itself to a simple sum of properties of its elements, was used. The combination of elements into the system is carried out as a result of their coherent interaction and induces the formation of something 'new' which has an integrative quality that these elements did not have before the unification. The main feature of the homogeneity system, which determines the existence of integrative properties (qualities), was also used. In any systems there are various relationships (relations) between the elements, but significant relations are only determined from the system positions, which reveal the integration properties of the system. The integrative properties of the elements differentiate the system from a simple conglomerate and identified it as a whole entity from the environment.

The modern economic theories of social welfare and human capital were also used.

The methods of observation, analysis and comparison were used to describe the main latest trends of the unevenness of spatial social development

The methods of generalization and extrapolation were used to ground the proposals for strengthening of social integration in terms of improvement of social protection and social security.

\section{Results and Discussion}

Social state is determined by qualitative characteristics and quantitative indicators of its properties including different indexes and standards. Quantitative social indicators together with comparative values determine the function of social policy norms as well as guidelines for the qualitative development of the country's economy.

European integration requires the implementation of the same package of financial, economic and institutional reforms for countries that seek to join the European Union. In the process of cooperation between Ukraine and the EU, the EU Program on Social Unity (hereinafter referred to as 'SU') was approved which is mandatory for EU members and candidates for EU membership. At the same time, there is no common EU social policy and implementation of measures in this area is primarily a responsibility of national governments. The EU agreed at the European Council meeting in Lisbon in March 2000 the Lisbon Strategy which introduced an 'open method of coordination' as a way for achievement of greater convergence towards the SU's main objectives (Employment, Social Affairs \& Inclusion).

The goals, objectives and political measures of the SU coincide largely with UNDP's goals, objectives and policies about human development as well as the Millennium Development Goals (MDGs) (United Nations (2017), Ukraine Millennium Development Goals 2000+5 (2005). Consequently, the focus of social policy on 
human development as well as a progress towards the achievement of the MDGs could bring Ukraine to the EU's social policy models contributing to EU membership and the living standards increase.

The Ministers for European Affairs of the EU Member States (at the informal meeting that took place on January 13 and 142010 in La Granja) confirmed that the new program 'Europe 2020' must replace the Lisbon Strategy and ensure a high level of economic growth and employment in the EU.

By signing the Millennium Declaration at the UN Summit in September 2000, Ukraine committed to achieve the "Millennium Development Goals" in development until 2015. The Sustainable Development Goals (SDGs), that were adopted by Ukraine on January 12, 2015, included 17 sustainable development goals that needed to be achieved by 2020 (and some until 2030). There were specific long-term challenges that were adapted to the development peculiarities of our country. The Council of the European Union finally approved the Association Agreement with Ukraine on July 11, 2017. Ukrainian financiers, businessmen and the general public have faced opportunities and challenges similar to those that were created decades ago in many Central European countries since this time.

The program envisages the achievement of the identified goals and the desired level of development, namely: the implementation of such financial and economic policy that determines the country's economic development through poverty eradication and social integration. The program has the following goals (Sustainable Development Goals (SDGs).

The first goal is to overcome poverty. Despite progress towards the Millennium Development Goals, around $17 \%$ of the world's population (more than 1 billion people) still live on $\$ 1.25$ a day or below. Emerging markets have fast grown during the last decade, and the volumes of financial resources earmarked from the private sector of these countries now exceed foreign aid making the private sector one of the key factors affecting the process of the global poverty overcoming. The situation in Europe can be characterized by the data (International Day for the Eradication of Poverty Downward trend in the share of persons at risk of poverty or social exclusion in the EU) in Figure 1.

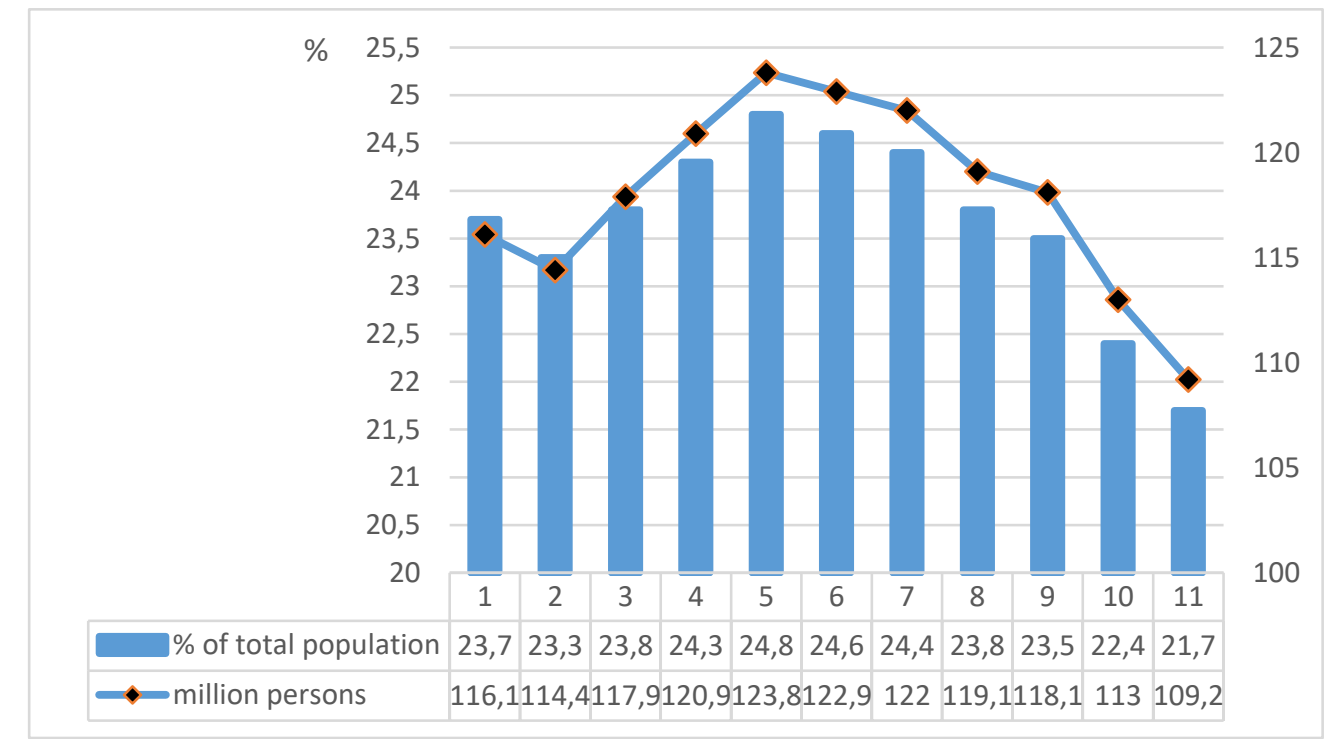

Figure 1. People at the risk of poverty or social exclusion in the EU, 2008/2018

Source: International Day for the Eradication of Poverty Downward trend in the share of persons at risk of poverty or social exclusion in the EU Eurostat newsrelease 158/2019. P. 2. Online. Available HTTP: https://appsso.eurostat.ec.europa.eu.

Some groups among the poor face with additional constraints such as limited access to resources for poverty alleviation. These are women, the disabled, children and indigenous peoples. For example, relative poverty remained virtually unchanged in the EU and situation with social payments only worsened in some countries (for example, Greece).

Enterprises must ensure respect for human rights including the rights of the above-mentioned groups. Entrepreneurs also have the opportunity to take measures to overcome the constraints for these groups for example through inclusive business models, innovative products and/or services that better meet the needs of 
such groups and through the use of the unique perspectives of these groups. as consumers, employees, suppliers and distributors in the value chain and members of society.

Overcoming poverty as a social phenomenon, public welfare is impossible without ensuring wage growth. The transition to wage growth policy expands purchasing power and stimulates the growth of production and services. It can be called the policy of 'developing growth' of wages. The main point is that wage increase causes a chain reaction in the processes of the consumer demand increase and production growth creating prerequisites for a new increase in wages.

The second goal is to overcome hunger, to achieve food security, to improve nutrition and to promote sustainable agricultural development. This aim shows the many problems of agriculture: the world's population must grow to 9 billion by 2050 with a decline in the number of rural labor force, deterioration of soil quality, climate change, loss of food, water shortages. It will lead to urbanization and more intensive use of protein diet. Increase of the productivity of agricultural products will provide food security for all only in terms of free access to safe and nutritious food in sufficient quantities.

The third goal is to ensure a healthy lifestyle and promote welfare for all people of all ages. Unsatisfactory health threatens the education rights of children, limits economic opportunities for men and women and increases poverty in communities and countries around the world. Significant progress was not being made last years. Reproductive health deteriorates among women throughout the world; thousands of new HIV/AIDS cases are recorded monthly; billions of people are left without access to medicines; millions of adults and children suffer from malnutrition; the total amount of waste grows. In particular, the spread of HIV/AIDS and tuberculosis is progressing in Ukraine.

The private sector must become a government partner to develop healthcare solutions that will affect individuals, households, communities and nations. Business is responsible for the observance of all human rights including the right to health. Small, medium and large companies can get economic benefits through social integration and contribute to the development of a healthy society.

The fourth goal is to provide qualitative education and to promote life-time learning for all. Effective social integration is possible with the maximum convergence of interests of both the state and its citizens. It seems impossible to achieve high economic indicators of development without creation of a system of social integration, namely: effective payroll, social benefits, financing of education and science and health care.

Ukrainian results in the field of qualitative education throughout life are ambiguous; many indicators are simply not controlled. In modern conditions, all relations and processes are not subjected to complete governmental regulation due the governmental limited capabilities in a market economy. Therefore, it is expedient to maximize the use of opportunities for social partnership for social integration and improvement of the welfare of citizens. Effective allocation of financial resources in the process of social integration will lead to its increase in the dynamic economic conditions of development.

The fifth goal is the achievement of gender equality and empowerment of women's opportunities to achieve at the expense of the gender ratio of both sexes at the level of at least 30:70 in the authorities as well as the reduction of the half-gap in the income of women and men.

Progress in gender equality is also not even. On the one hand, women are more successful in education than men but earn less men. On the other hand, women are represented not enough in politic especially in parliament and government particularly in Ukraine. At the same time, indicators of gender equality are not monitored enough. The gap between men's and women's life expectancy is increasing.

The sixth goal is an access to water and sanitation including the long-term access to clean water and providing sanitary conditions for all stakeholders.

The seventh goal - an access to affordable, reliable, stable and modern energy for all - involves promotion of entrepreneurship for acceleration of the transition to an affordable, reliable and sustainable energy system by investing in renewable energy sources.

The eighth goal is to promote sustainable and inclusive economic growth, full and productive employment and decent work for all. The main problem is the low conditions of work that are often associated with poverty, inequality and discrimination. Several groups such as disabled workers, women, young people and migrants 
face with especial barriers to decent work and can be particularly vulnerable to abuse. This goal entails the consolidation of social partnership that means the conclusion of general and sectary labor agreements, collective agreements. They provide a wide range of social support and protection measures for the ablebodied population taking into account the specifics and capabilities of enterprises, the region, and the industry.

The ninth goal is key goal for the development of social integration in all parts of the world. It is a creation of a reliable infrastructure, the promotion of inclusive and stable industrialization and the promotion of innovation. The main objective of this goal is the development of a high-quality, reliable, stable and sustainable infrastructure including regional and cross-border infrastructure in order to support economic development and human welfare in the aspect of affordable and equal access to work for all categories of people and promotion of inclusive and stable industrialization.

The tenth goals are the reduction of inequality within separate country and between countries. The main problem is the rising income inequality around the world. The richest $1 \%$ of the world's population today controls up about $40 \%$ of world assets and the poorest - only $1 \%$. There are widespread and often complementary disparities in many countries that include inconsistencies in terms of income disproportions in rural/urban households, the welfare of the population, gender, ethnic minorities and indigenous peoples, the status of migrants and disabled people. To reduce inequality entrepreneurs can use inclusive business models that empower marginalized groups in the workplace, market and society.

The eleventh goal is to make cities and settlements safe and sustainable. According to world estimates, 70\% of the planet's population will live in cities by 2050 making cities unsafe. Therefore, it is necessary to invest in a safe and stable urban infrastructure.

The twelfth goal is to provide sustainable patterns of consumption and production. It is expected that the most people around the world will join the middle class during the next two decades. These social, economic and demographic changes are useful for improvement of individual welfare but increase the demand for limited natural resources. The first step should be to find greater potential for improvement of the environmental and social impact.

The thirteenth goal is the introduction of urgent measures to combat climate change and its negative effects. The world must anticipate, adapt and become resistant to the current and expected effects of climate change in the future. Entrepreneurs must slow down this process through decarburization of industries, increase of energy efficiency, reduction of carbon emissions from their products and investment in the development of innovative low carbon products.

The fourteenth goal is a conservation and effective use of oceans and seas for sustainable development. The world's oceans are threatening by pollution, resource depletion and climate change primarily due to human activity. These threats make additional pressure on environmental systems such as biodiversity and natural infrastructure creating global social and economic challenges including health, safety and financial risks. Global leaders should work to protect marine production and to support people dependent on the oceans.

The fifteenth goal is the protection, reproduction and promotion of sustainable use of terrestrial ecosystems, sustainable forest management, the fight against desertification, the cessation and reversal of land degradation and the cessation of biodiversity loss. This goal is almost out of reach, because all monitored indicators show no progress. Sustainable management of land and forest resources is key issue to maintain the integrity and viability of natural resources.

The sixteenth goal is to promote peaceful and inclusive societies for sustainable development. The goal is to carry out risk assessment and impact assessment in order to identify and minimize the risks associated with corruption, violence and conflicts, weakness of the law.

Finally, the seventeenth goals are to strengthen the means of implementation and intensification global partnership for sustainable development. The goal means to help developing countries to achieve long-term debt sustainability through a coordinated policy directed to debt financing, debt relief and debt restructure and debt relief for poor countries with high indebtedness as well as introduction of a regime of investment incentives for the least developed countries.

Some projects of social integration were implemented in Ukraine. 
1. 'Social integration of disabled people through access to employment' is a joint project of UNDP and the International Labor Organization (ILO) in Ukraine with term 01.09.2008-01.01.2012. The project was sponsored by UNDP, ILO. As disabled people make up one of the most vulnerable groups in Ukraine (which is almost 2.6 million people, or $5.6 \%$ of the total population and only $14 \%$ of disabled people are employed) the project's objectives have become extremely important for increase of the level of welfare of vulnerable people. The budget of the project amounted to 298000 USA dollars. However, the Program has been partly implemented and some stages have not yet been completed. New mechanisms to encourage employers to hire workers with disabilities and to organize training and involvement of especial staff (in particular on labor rehabilitation; on the organization/adaptation of the workplace and the creation of a special workplace (ergonomists); instructors on labor adaptation and support of disabled workers in the workplace) have not been put into practice.

2. 'Social integration and development of civil responsibility of youth' is a project the main task of which is to provide conditions for effective social integration of young people, the use of information and communication technologies as an instrument for the support of social activity of youth, creation of an enabling environment for the implementation of socially oriented projects. Young women and men received relevant knowledge and skills through innovative approaches in the project framework. Term for implementation: 01.12.2008-01.12.2010. There were 3 donors of the Project: UNDP, ILO UN Volunteer Program, INTEL Ukraine Microelectronics Ltd, which created a total budget of 1199300 USA dollars. All regions of Ukraine continue to actively involve young people in active participation in social processes and decision-making processes after project finish.

Consequently, the mission of the SDGs is to ensure the positive impact of social development on the poorest and marginalized groups of the population. Progress depends on the concerted efforts of governments and all stakeholders including public organizations, non-governmental organizations and other participants.

Sustainable development should not be focused only on the regular assistance to the poor but on encourage of their personal development, strengthening of their role in society and expansion of opportunities to choose their own future while ensuring that they take responsibility for their choice. Individuals become the center of human progress because human development is not only a decisive goal but also an important factor in social and economic development and a factor of public welfare increase.

Ukrainian social policy is passive and focused mainly to help the poor rather than to reduce poverty expanding the capabilities of these strata of the population. It caused a culture of dependence when beneficiaries become passive recipients who rely on material assistance.

The modern system of social protection of both Ukraine and most European countries with a post-socialist past suffers from typical deficiencies. Governments usually provide assistance to a large number of beneficiaries beyond its financial capacity. At the same time, the level of social payments is very low and does not solve the problem of poverty. In addition, social assistance together with the low average wage do not encourage people to engage in economic activity which ensures dependence on material assistance.

One of the important issues is the social protection of the poor and vulnerable groups of the population through allocation of financial resources in the process of social integration. Social protection is a system of social policy measures aimed at the observance of social rights, the satisfaction of social needs. Social protection during the provision of social integration is manifested in the system of priorities and mechanisms for the implementation of legally established financial, social, economic and legal guarantees of citizens; includes a system of social services, bodies, institutions that provide a certain level of social protection, achievement of socially acceptable level of welfare of citizens with special needs and different age groups in accordance with changing conditions of social development.

The criteria for social unity are adequate to the three social spheres of social policy which are related to social integration. Each of them also consists of a number of economic goals and indicators of its financial support. Social spheres include: (1) eradication of poverty and social exclusion; (2) adequate and stable pensions; (3) accessible, qualitative and stable health care.

Today the EU is inclined to implement a strategy of cooperation that involves cooperation not only with the EU members, non-governmental organizations and social partners, but also with countries which seek to become full members of the EU in the future. This strategy has seven main priorities for this countries: 
1. To increase participation in the labor market by expansion of active policy and provision of the better link between social protection, education and lifelong learning.

2. To modernize the system of social protection ensuring their stability, adequacy and accessibility for all.

3. To eliminate barriers in education and training investing additional funds in human capital in particular focusing on the most disadvantaged groups.

4. To eradicate child poverty guaranteeing the education of children, increasing the assistance to their families, protecting their rights.

5. To provide decent housing for vulnerable groups and to develop integrated approaches to overcome homelessness.

6. To improve access to qualitative services in such spheres as health care, social services, transport, new information and communication technologies.

7. To maintain gender equality and to improve the social integration of people with disabilities, ethnic minorities and immigrants.

SIGMA (Support for Improvement in Governance and Management) and 'Ukraine - Governance Assessment' (March 2006) is one of the programs helping candidate countries to the EU, potential candidates and neighboring countries to set up their public services, to reform their public administrations and to strengthen their administrative and legal framework. This process helps them to realize reforms and improve its effectiveness disseminating the experience among the EU member states. The EU will not contribute more effectively to the implementation of this process through the ENP in the near future regarding Ukraine because there is the major gap in economic development and living standards between the new EU members and candidate countries as well as potential candidates.

The status of an 'associate member' can attract financial resources to the Ukrainian economy. The ENP aims to build a privileged partnership with neighboring countries bringing them closer to the Union and providing them a share in the Community's domestic market while supporting dialogue, reforms and social and economic development. These measures have a clear integrative aspect and are usually caused by conditions of the assistance provision for development and improvement of public welfare.

The basic principle of social support in the process of social integration should be the targeted approach to social assistance and the abandonment of the class benefits. Increase of targeting allows to use effectively the available financial resources to provide real help to the most in need not losing the incentive to work. The targeted assistance should be in the directions: provision of minimum social standards guaranteed by laws; one-time targeted assistance through the implementation of targeted government programs for support of socially vulnerable populations; providing of social services for the disabled. It must be taken into account that the quantitative scale of social assistance should be sufficient to prevent the illegal enrichment of the poor and at the same time not to be discouraged so as not to stimulate the expansion of this group and the loss of incentive to work.

Determination of the required amount of financial security for public welfare is a complicated and ambiguous process since it, on the one hand, depends on the composition and size of the needs of society and, on the other hand, is limited by real financial resources. The level of public welfare can be characterized on the basis of the evaluation of the material situation of individuals and social and economic results of society development during the study period. The stability of the financial support for public welfare depends on the pace of scientific and technological progress, social technologies and innovations.

Improvement of public welfare can be ensured through the achievement of:

$>$ rational employment;

$>$ adequate system of human vital activity;

$>$ reproduction of labor resources etc.

According to the conducted researches, the most complete realization of social integration is possible taking into account a combination of factors, processes and results that both directly and indirectly focus on satisfaction of different and rapidly growing needs and interests of citizens.

For example, legislative and normative acts which regulate the processes of social integration should be aimed to solve organizational problems such as:

restructuring of the social sphere with the purpose of wide introduction of social integration; 
$>$ modernization of the social activity principles in order to reduce the population demand for the social assistance;

$>$ development of regional and governmental investment programs in order to increase public welfare.

Therefore, the priority measures to enhance social integration in Europe can be highlighted:

1. Support the development of adequate social protection systems and employment policies.

2. Modernization of the legislation and its effective application.

3. Promotion of the geographical mobility and employment opportunities through the development of an open labor market.

4. Increase of the availability of micro financing for vulnerable groups and micro enterprises and social enterprises.

Thus, social technologies for regulation of the public welfare level should include the spheres: labor and wages, education and personal development, social protection, social integration and social partnership.

\section{Conclusions}

In order to strengthen the humanization of economic relations and public welfare increase it is necessary to improve such integration processes as: support for the welfare of the individuals and households; poverty alleviation; strengthening of social integration; reduction of social inequality; increase of economic efficiency of the real sector of the economy. The general result of these economic processes is the achievement of a higher level of public welfare. Market only leads to the desired social changes when government acts as one of the agents of the market stimulating economic activity.

In order to strengthen and to intensify social integration it is necessary to continue work on:

$>$ improvement of the regulatory framework and financial mechanisms aimed at creation of an effective system for targeted social payments;

$>$ implementation of the main measures set that will lead to the development and improvement of social integration of individuals, women, youth and children;

$>$ development and implementation of measures for the prevention of disability and social integration of the disabled;

$>$ active involvement of non-governmental organizations and public associations in the process of social integration.

The European Commission calls national governments in Europe to create equal opportunities for various strata of the population and individuals with different needs, to reduce labor market disparities, to maintain economic competitiveness and to monitor employment policies.

Nowadays there are EU laws for limitation of working hours, fight with discrimination at work and improvement of work conditions. The EU promotes social security and social integration providing and coordinating funding to help European countries invest in people in areas such as childcare, health care, education, accessible infrastructure, job search assistance and public welfare reformation.

The EU and national governments work together to coordinate social security schemes in the EU so that workers continue to receive pensions and social security payments when they change jobs and work in different EU countries. EURES is a network of European employment services that helps companies hire people from abroad and people to work abroad.

Financial support for the processes of social integration strengthening is provided through EU funding programs (Employment and social affairs):

$>$ European Social Fund (ESF);

$>$ European Globalization Adjustment Fund (EGF);

$>$ Fund for European Aid to the Most Deprived (FEAD);

$>$ EU Program for Employment \& Social Innovation (EaSI), which includes: PROGRESS, EURES;

$>$ Microfinance \& social entrepreneurship.

The EU Programmer for Employment and Social Innovation (EaSI) is a financial instrument to promote a high level of quality and sustainability of employment guaranteeing adequate and decent social protection, combating social exclusion and poverty and improving working conditions. The total budget for 2014-2020 
is EUR 919469000 in 2013 prices. The Sustainable Development 2020 strategy for smart, sustainable and inclusive growth aims to bring at least 20 million people will come out from poverty and social exclusion and to increase employment for people aged 20-64 to $75 \%$.

Implementing the EaSI program, countries can pay particular attention to vulnerable groups such as young people; promote equality between women and men and fight against discrimination; promote a high level of quality and sustainability of employment; ensure adequate and decent social protection; fight against longterm unemployment; fight against poverty and social exclusion.

Taking into account changes in property relations, social integration as an integral element of economic development implies the comprehensive development of social partnership. It means that every economic entity (state, trade unions, employees, public organizations and associations) seeks to create conditions for the normal reproduction of the physical and mental forces of the worker and his (her) development. Obviously, the principle of social partnership does not work automatically. In fact, this is achieved resolving the contradictions between the employer and the workers, government and employers about wages, taxes, work and rest conditions, etc. Agreements about these issues are achieved through the strengthening of social integration in providing of social support for every individual in society. Eventually, it will provide humanization of economic relations and improvement of public welfare.

The processes of social integration should be manifested in public finance policy in the aspect of social protection. Predominant causes of poverty, which stem from the objectively existing inequality, is the objective inevitability of the demographic, social and financial heterogeneity of developed countries societies. In Ukraine these causes are intensified by economic, social and politic crises and military conflict.

\section{References}

1. About the Strategy of Sustainable Development 'Ukraine 2020': The Decree of the President of Ukraine 12.01.2015. Online. Available HTTP: http://zakon1.rada.gov.ua/laws/show/5/2015.

2. Social Integration: Approaches and Issues (March 1994). UNRISD Briefing Paper No. 1 World Summit for Social Development, United Nations Research Institute for Social Development. P. 5. DOI: https://doi.org/10.1080/0961452951000157004.

3. George Elton Mayo (1946). The Human Problems of an Industrial Civilization Hardcover. Macmillan; 2nd edition. 194 p. DOI: https://doi.org/10.1177/000271623417200135

4. Robert Owen (1817). A new view of society: or, essays on the formation of the human character, preparatory to the development of a plan for gradually ameliorating the condition of mankind. London: Printed for Longman. 3d edition. 184 p. https://catalog.hathitrust.org/Record/011257473

5. McGregor, D. (1960). The human side of enterprise. New York, NY, US: McGraw-Hill. 256 p. https://www.worldcat.org/title/human-side-of-enterprise/oclc/173969

6. Abraham H. Maslow (1954). Motivation and Personality. New York: Harper, pp. 120-132. https://www.eyco.org/nuovo/wp-content/uploads/2016/09/Motivation-and-Personality-A.H.Maslow.pdf

7. Alderfer Clayton P. (May, 1969). An Empirical Test of a New Theory of Human Needs. Organizational Behavior and Human Performance, 4(2), 142-175. DOI: https://doi.org/10.1016/0030-5073(69)90004-X

8. Herzberg, Frederick (1966). Work and the Nature of Man. Cleveland: World Publishing, 203 p. https://www.worldcat.org/title/work-and-the-nature-of-man/oclc/243610

9. Pigou, Arthur Cecil (1920). The Economics of Welfare. London: Macmillan and Co. Pub. Date 1932. Part 12. http://files.libertyfund.org/files/1410/Pigou_0316.pdf

10. Daniel Bell (1973). The Coming of Post-Industrial Society: A Venture in Social Forecasting. New York: Basic Books. 508 p. https://www.amazon.com/Coming-Post-Industrial-Society-Venture-Forecasting/dp/0465097138

11. R. F. Kahn (Jun., 1931). The Relation of Home Investment to Unemployment. The Economic Journal, 41(162), 173-198. https://www.scirp.org/(S(i43dyn45teexjx455qlt3d2q))/reference/ReferencesPapers.aspx?ReferenceID=142918 4

12. J. Viner (1925). The Utility Concept in Value Theory and its Critics. Journal of Political Economy, 33(4), 369-387; 6, 638-659. DOI: http://dx.doi.org/10.1086/253725

13. Russell Lincoln Ackoff, Frederick Edmund Emery (1972). On purposeful systems. Chicago: AldineAtherton, 288 p. DOI: https://doi.org/10.1080/00140137308924562.

14. Employment, Social Affairs \& Inclusion / European Commission, Brussels: Online. Available HTTP: http://ec.europa.eu/social/main.jsp?catId=750\&furtherPubs=yes\&langId=en. DOI: $\underline{10.2767 / 062945}$ 
15. United Nations (2017). General Assembly Resolution 51/59 on Action against Corruption Online. Available HTTP: https://www.cambridge.org/core/journals/international-legal-materials/article/unitednations-general-assembly-resolution-5159-on-action-againstcorruption/540789329B92E4EC92225E3A2A18F110 (Published online: 27 February 2017). DOI: https://doi.org/10.1017/S0020782900015205.

16. Millennium Development Goals Report. Online. Available HTTP: https://www.un-ilibrary.org/economicand-social-development/millennium-development-goals-report_98544aa9-en.

DOI: https://doi.org/10.18356/98544aa9-en

17. European Union|Ukraine. Online. Available HTTP: https://euroquiz.org.ua/data/blog_dwnl/UKREU_2018_30082018_FINAL_web.pdf. DOI: $10.2871 / 95746$.

18. Sustainable Development Goals (SDGs) in Ukraine / United Nations Ukraine. Online. Available HTTP: http://sdg.org.ua/en/sdgs-and-civil-society.

19. UNDP, ILO help national counterparts in implementing the UN Convention on the rights of persons with disabilities / United Nations in Ukraine. Online. Available HTTP: http://www.un.org.ua/en/news/201003-18/?mosmsg.

20. 'Ukraine - Governance Assessment' (March 2006), p. 75. Online. Available HTTP: http://www.sigmaweb.org/dataoecd/46/63/37127312.pdf (accessed 15 December 2007).

21. Employment and social affairs/European Union. Online. Available HTTP: https://op.europa.eu/en/publication-detail/-/publication/e0338cf4-d832-11e9-9c4e-01aa75ed71a1. DOI: $10.2775 / 14401$.

22. EU Programmer for Employment and Social Innovation (EaSI) / European Union. Online. Available http: http://ec.europa.eu/social/main.jsp?catId=1081\&langId=en.

23. Rowley C. K. (2004). The Encyclopedia of Public Choice. USA: Kluwer Academic Publisher, 1004 p. DOI: 10.1007/s11127-006-3475-2.

24. Labour standards. International Labour Organization. Online. Available HTTP: http://www.ilo.org/wcmsp5/idcplg?IdcService=COLLECTION_DISPLAY\&hasCollectionID=true\&dC ollectionID=2.

25. Martius Georg, Herrmann Michael, Der Ralf (2007). Self-organisation for Autonomous Robot Development Advances in Artificial Life 9th European Conference 'MPI für Dynamik und Selbstorganisation»/Nichtlineare Dynamik'. Online. Available at: http://edoc.mpg.de/display.epl? mode $=$ doc $\&$ id $=350217 \&$ col $=43 \& g r p=239$.

26. Alex C. Michalos (1980) Development of Quality of Life Theory and Its Instrument. The Selected Works of Alex C. Michalos. Chapter 2. Satisfaction and Happiness. 5-39. DOI: 10.1007/978-3-319-51149-8

27. Population estimates. Monthly Report. Ministry of Internal Affairs and Communications. Online. http://www.stat.go.jp/english/data/jinsui/tsuki/index.htm

28. Society. The official gateway to Sweden. Online. Available http: http://www.sweden.se/eng/Home/Society/

29. Strategy. The World Bank. Online. Available http: http://www.worldbank.org/html/extdr/thematic.htm

30. G. S. Becker (1965). A Theory of the Allocation of Time. Economic Journal, 75 (299), 497-517. DOI: https://doi.org/10.2307/2228949.

31. Herbert A. Simon (1997). Administrative behavior: a study of decision-making processes in administrative organization. New York: A Division of Simon \& Schuster Inc. 368 p. 4th ed. https://jespersimonsen.dk/Downloads/Simon-introduction.pdf

32. Documentation. United Nation Economic and Social Council. Online. http://www.un.org/en/ecosoc/docs/docs.shtml.

33. Easton D. A. (1965). Systems Analysis of Political Life. New York: Wiley, 507 p. DOI: https://doi.org/10.1002/bs.3830130208.

34. Bertalanffy L. von Bertalanffy (1950). An Outline of General System Theory. British Journal for the Philosophy of Science, 1, 134-165. https://doi.org/10.1093/bjps/I.2.134.

35. Campbell A., Converse P., Rodgers W. (1976). The Quality of American Life. USA: N.J. 583 p. https://deepblue.lib.umich.edu/handle/2027.42/99153

36. International Day for the Eradication of Poverty Downward trend in the share of persons at risk of poverty or social exclusion in the EU Eurostat news release 158/2019. Online. Available http: DOI: https://appsso.eurostat.ec.europa.eu. 